УДК 94 (54) «1947/1999»

DOI: https://doi.org/10.33782/eminak2019.2(26).298

\title{
ОСОБЛИВОСТІ ІСТОРИЧНОГО РОЗВИТКУ ДЕРЖАВНОСТІ ПАКИСТАНУ
}

\author{
Ігор Горобець \\ Сумський державний педагогічний університет імені А.С. Макаренка (Суми, Україна) \\ e-mail: gorobech.igor@gmail.com \\ ORCID: https://orcid.org/0000-0002-2416-7898
}

У статті проаналізовано основні особливості історичного розвитку державності Пакистану. Відокремлення Пакистану від Британської Індї 1947 р. було обумовлено передусім ідеєю створення «чистої» ісламської держави. Відтоді ісламський фактор став визначальним для еволюції пакистанської державності. Доведено, що формування пакистанської політичної нації ускладнено міжетнічними, міжконфесійними, соціальноекономічними та регіональними протиріччями.

Ключові слова: державність, іслам, суніти, шиїти, Пакистан, Південна Азія, ядерна зброя

Актуальність дослідження особливостей історичного розвитку державності Пакистану обумовлена помітним місцем, яке ця країна займає серед мусульманських держав світу, а також суттєвим впливом на розвиток країни крайніх форм ісламістської ідеології. Внаслідок цих тенденцій Пакистан є потужною силою дестабілізації ситуації у Південній Азії й у світі. 3 часу поділу Британської Індії Пакистан об’єктивно опинився під впливом негативної для себе асиметрії у геополітичній, економічній і військово-політичній сферах взаємодії з Індією. Варто погодитись 3 думкою відомого американського аналітика 3. Бжезінського, який писав, що «хоча Пакистан озброєний новітньою ядерною зброєю, а його цілісність гарантує сучасна професійна армія, більшість жителів країни - окрім політичного активного середнього класу та мешканців густонаселених міст - відсталі, живуть у селах й ототожнюють себе з окремою місцевістю чи племенем» ${ }^{1}$. У такому стані Пакистан вступив у XXI cT.

Метою статті $€$ висвітлення історичної специфіки формування та розвитку пакистанської державності.

Огляд публікацій. Індійський науковець Вікрам Суд дослідив проблеми становлення та сучасний стан радикального ісламу у регіоні Південної Азії . Ще один індійський науковець Джон Вільсон дослідив особливості відносин радикального ісламу 3 пакистанськими державними структурами ${ }^{3}$.

В 1947 р. у Карачі був заснований Інститут міжнародних відносин Пакистану, який спеціалізується на дослідженні міжнародних відносин і зовнішньої політики Пакистану, видаючи щоквартальний журнал «Pakistan Horizon».

Дослідник Алок Матхур у своїй монографії констатує кризу пакистанської ідентичності, які формувалася на основі теорії двох націй 4 .

\footnotetext{
1 Бжезінський 3. Стратегічне бачення. Америка і криза світової влади. Львів. 2012. С. 81.

2 Белокреницкий В.Я., Москаленко В.Н. История Пакистана. XX век. Москва, 2003. С. 52.

3 Плешов О. Ислам и политическая культура общества. Парадоксы консервативной традиции // Азия и Африка сегодня. 2003. № 2. С. 20

4 Энциклопедия Пакистана. Москва, 1998. С. 15.
} 
Наприкінці 2008 р. пакистанське посольство у Вашингтоні очолив відомий політолог Х. Хаккані, якому належить відома праця, присвячена ролі військових у політичному житті Пакистану5.

Проблемам адаптації зовнішньої політики Пакистану до сучасних міжнародних реальностей присвячена монографія М. Хафізаб.

У вітчизняній історіографії пакистанська тематика висвітлюється у монографії П.М. Ігнатьєва, яка присвячена ролі Індії у регіоні Південної Азії. Ширше історія Пакистану висвітлюється російською історіографією. Провідні позиції у дослідженні зазначеної проблематики займають В.Белокреніцький, Р. Мукимджанова, О. Плєшов. Звичайно, розвиток українсько-пакистанських відносин на сучасному етапі залежить від адекватного розуміння процесів, які відбуваються у цій південноазійській країні. Власне цьому й присвячено нашу статтю.

Річка Інд поділяє Пакистан, розташований на стику Південно-Західної, Центральної та Південної Азії, на дві частини, обумовлюючи подальший поділ країни на провінції. Західніше розташовані малонаселені Північно-Західна прикордонна провінція та Белуджистан, які межують з Афганістаном та Іраном. Пакистан є федерацією племен зі слабкими центральними інститутами, хоча країні досталася кваліфікована еліта постколоніального періоду. На історичному етапі розподілу Британської Індії «політичний розвиток Пенджабу, Східної Бенгалії, Сінду, Північно-Західної прикордонної провінції, Белуджистану завершився їхнім об’єднанням у мусульманській державі», але «дестабілізуючий вплив етнічно релігійного фактору не був нейтралізований вже у незалежному Пакистані»8.

Прихильники ідей радикального політичного ісламу з'явилися у Британській Індії ще на початку XIX ст. Але вже на початку XX ст. вони зберегли свої позиції лише у Північно-Західній Прикордонній провінції серед пуштунів. Зазначена провінція була утворена британською колоніальною адміністрацією у 1901 р. Відтоді провінція залишається «гарячою точкою». 17 липня 1947 р. на референдумі більша частина населення зазначеної провінції проголосувала за входження до Пакистану9. Частина пакистанських мусульман вважають іслам досконалою релігією, яка не потребує західної моделі демократії. Інші вважають, що іслам демократичний за своєю суттю. Вони переконані, що мусульмани вірять у рівність можливостей, відповідальність духовних і світських керівників перед Аллахом і людьми, право останніх вільно висловлювати свою точку зору. У відповідь радикальні ісламісти називають західні форми освіти несумісними з ісламськими цінностями. Усі мечеті у Пакистані належать державі. За підрахунками російського сходознавця Ю. Тиссовського, майже 70\% пакистанських мулл займаються політичною діяльністю10. Зрозуміло, що для пакистанської ідентичності, яка грунтується на ісламі, викликом є сам факт, що за чисельністю мусульман Індія $є$ другою мусульманською країною світу після Індонезiї.

Територіальний поділ Британської Індії 1947 р. перетворив пакистанську провінцію Сінд на пристанище для біженців з Індії. На початку 1990-х рр. етнічні проти-

\footnotetext{
${ }^{5}$ Haqqani H. Pakistan: Between Mosque and Military. Washington. 2005. P. 29.

${ }^{6}$ Hafeez M. Pakistan: Founders aspirations and today's realities. Oxford. 2001. P. 44.

7 Ігнатьєв П.М. Індія на шляху до лідерства в Південній Азії. Чернівці. 2006.

8 Ibid. C. 86.

9 Белокреницкий В.Я., Москаленко В.Н. Указ. раб. С. 94.

10 Тыссовский Ю.К. «Крестоносцы» против ислама. Москва: Наука, 2011. Т. 1. С. 288.
} 
річчя провокують конфлікт між вихідцями з Індії «мухаджирами» та пенджабцями й пуштунами. Центром цього протистояння $є$ місто Карачі. Російський дослідник О. Плєшов, визнаючи іслам як інструмент творення пакистанської політичної культури, наголошує на відмінностях між «міським ісламом» богословів улемів і «сільським народним ісламом». На відміну від «народного ісламу», пов'язаного з регіональною етнічною культурою та толерантністю до інакодумства, міський іслам $€$ більш нетерпимим і схильним до кровопускання ${ }^{11}$. Водночас треба мати на увазі, що мусульманська громада Пакистану поділяється на нащадків арабів, персів, тюрків, афганців, які сюди переселилися та нащадків навернених у мусульманство індійців.

Загалом для політичної системи Пакистану, як слушно зазначає російський дослідник В.Я. Белокреніцький, властивим $€$ «персоналістський авторитаризм як авторитарний режим влади, за якого персона правителя відіграє символічну, законодавчу, виконавчу владу та спирається у своїх діях на сприяння найближчого оточення»12. Збройні сили в умовах авторитарних режимів не лише $\epsilon$ інструментом влади правлячих бюрократичних угруповань, а й безпосередньо впливають на політичні процеси, трансформацію соціальних структур, розробку основних напрямків внутрішньої та зовнішньої політики. Для Пакистану не властива ситуація, коли військові виступали за демократизацію та лібералізацію режиму. Адже це не відповідає їхній ментальній традиції та соціальній ідентифікації.

У науковій літературі можна знайти опис політичного циклу історії Пакистану, який вписується в алгоритм: військова диктатура, генерал-президент, повстання проти нього військової хунти, вибори, цивільний уряд, економічний і соціальний хаос, військовий переворот. Попри наявність двопалатного парламенту, досить впливового суддівського корпусу, який складається із суддів Верховного Суду та Федерального шаріатського суду, бурхливого багатопартійного життя, Пакистан демонструє традиційні суперечності між президентським і прем'єрським інститутами влади. Конституція Пакистану лише зобов'язує зміцнювати братські зв'язки 3 мусульманськими країнами. Офіційні концепції зовнішньої політики, національної безпеки або оборони Пакистану не приймаються. Але це не означає, що зазначені процеси взагалі не мають доктринальних засад.

На нашу думку курс мусульманської еліти на відокремлення від Індії пояснюється соціально-політичними інтересами цієї еліти. Адже мусульманська еліта складалася із землевласників та ісламського духовенства. Їх не влаштовувала ідея демократичного правління, яка неминуче мала привести до земельної реформи та секулярного законодавства. Тож створення Пакистану за таких умов видавалося неминучим. Але й проблеми з демократією також обумовлюються «генетичним» походженням пакистанської державності та соціальною структурою цього суспільства.

На момент проголошення незалежності Пакистану рівень грамотності у країні не перевищував $13 \%$ населення ${ }^{13}$. Не вистачало середніх шкіл для хлопчиків, не кажучи вже за дівчаток. Більшість вищих наукових і дослідницьких центрів залишилися в Індії. «Батьки-засновники» Пакистану сподівалися поєднати у системі освіти досягнення західної цивілізації з нормами та цінностями ісламу. Це обумовило гібридизацію традиціоналізму й обережної модернізації. Регіональні політичні уподобання у

\footnotetext{
11 Плешов О.В. Ислам, исламизм и номинальная демократия в Пакистане. Москва, 2003. С. 255.

12 Белокреницкий В.Я. Персоналистский авторитаризм в Пакистане (к вопросу о политической культуре и режиме власти в восточном варианте) // Восток. 2005. № 6. С. 74.

13 Плешов О.В. Ислам, исламизм и номинальная демократия в Пакистане... С. 183.
}

Eminak, 2019, 2 (26) 
Пакистані спираються на інтереси великого капіталу провінції Сінд і переважно аграрного Пенджабу. Причому вихідці з Пенджабу складають більшість у державному апараті та пакистанській армії. Пакистану властива кланова боротьба представників провінції, яка контролює владу, спрямована на знищення бізнесу політичної еліти іншої провінції. Ця специфіка робить недієздатною усі випробувані у пакистанському середовищі політичні системи: парламентську, президентську, військову та гібрид парламентсько-президентської влади. Пакистану також властиве насилля між представниками різних етнічних і релігійних груп. Підхід «батька» пакистанської нації М.А. Джинни до формування державних структур Пакистану грунтувався на ідеї світської держави з міцними мусульманськими традиціями, що до певної міри нагадувало концепцію «батька» усіх турків - Ататюрка. Але після смерті М.А. Джинни в 1948 р. у Пакистані помітно активізувалися ісламські фундаменталісти ${ }^{14}$.

Ідейним натхненником сучасного ісламського фундаменталізму у Південній Азії $\epsilon$ Абдулла Абу-ль-Аала Маудуді (1903-1979). Він ще 1941 р. створив партію «Джамааті-ісламі», яка виступала проти секулярної демократі. Наприклад, з 58 релігійних політичних партій, які існували на час заснування Пакистану, двома найбільш потужними є «Мусульманська ліга» (створена у грудні 1907 р. в Карачі) та «Джамаат Улема-і-іслам»15. Остання $\epsilon$ найбільш впливовою релігійно-політичною організацією Пакистану, яка виступає за встановлення «ісламського порядку» у всьому світі. Партія була створена 25 серпня 1941 р. й до 1972 р. іï̈ лідером був А.А. Маудуді. Партія морально-політично підтримує афганський рух Талібан. Серед сунітів найбільш непримиренно до іновірців ставляться улеми-барелві, які 1948 р. створили партію «Співтовариство пакистанських богословів»16. Потужними були ісламські інтеграційні й інтернаціональні інтенції. Зокрема, у 1952 р. на території Пакистану була створена «Партія ісламського звільнення» (Хізб ут-Тахрір аль-Ісламі), яка ставить собі за мету усунення від влади у мусульманських країнах світських режимів, запровадження у них суто ісламських форм правління та інтеграцію в єдину державу17.

У 1953 р. пакистанські шиїти створили власну суспільно-політичну організацію «Шиїтська конференція». До конфесії шиїтів належить олігархічний клан родини Хабібів. Цікаво, що ісмаїліти також неоднорідні та складаються із двох сект: нізарітів і мусталітів. Така конфесійна строкатість пакистанського суспільства також перешкоджає «єдиному ортодоксальному» формуванню зв'язків між ісламом і політикою.

У 1954 р. Індія остаточно оголосила свою частину Кашміру власним штатом. Внаслідок цього позиція Пакистану ще більше стала радикальною. Зазначимо, що до 1954 р. у політичному житті Пакистану домінувала «Мусульманська ліга». За цей час посилилися економічні та політичні протиріччя між Західним Пакистаном і Східним Пакистаном. Нездатність правлячої партії розв'язати нагальні проблеми стимулювала появу опозиційних партій: «Авамі ліг» (Народна партія), «Азад Пакистан» (Вільний Пакистан) та інших ${ }^{18}$. У Пакистані склався так званий істеблішмент, який на-

\footnotetext{
14 Тыссовский Ю.К. «Крестоносцы» против ислама. Москва, 2011. Т. 1. С. 62.

15 Филимонова А.Л. Этнорегионализм versus мусульманская общность в Британской Индии // Восток. 2010. № 5. С. 86.

16 Энциклопедия Пакистана... С. 82.

17 Mathur Alok. «The 2-nation Theory». A Study in the Context of Crises in Pakistan. Jaipur. 1994. P. 190.

18 Викрам Суд. Радикальный ислам в регионе и его влияние на Южную Азию // Радикальный ис-
} 
раховує 400-500 осіб, пов'язаних між собою кланово-родинними та соціальноінституційними узами, які визначають внутрішню та зовнішню політику країни.

29 лютого 1956 р. Установчі збори прийняли Конституцію, яка проголосила Пакистан федеративною Ісламською республікою та встановила парламентську форму правління. Торговельно-промислові кола Пакистану були невдоволені монополією на владу земельних власників. В умовах внутрішньополітичного хаосу 8жовтня 1958 р. пакистанська армія здійснила військовий переворот. Главою держави став генерал М.Айюб-хан (1907-1974). Він народився у небагатій пуштунській родині, воював з японцями у Бірмі, навчався у британському військовому коледжі «Сандхерст». Айюб-хан намагався, спираючись на підтримку армії, бюрократії всередині Пакистану, а також США, за його межами модернізувати країну «згори» ${ }^{19}$. Військові репресивними засобами намагалися «підморозити» високий градус суспільного невдоволення. До земельної реформи 1958 р. на клан Бхутто у провінції Сінд, - за спогадами Беназір Бхутто, - працювала більшість сільськогосподарських робітників 20.

У 1958-1971 рр. пакистанські військові тримали владу в країні у своїх руках. Потребу цього обумовлювали соціально-економічні та сепаратистські проблеми. Військові намагалися діалектично поєднати практику «республіки» та поняття «іслам». Армія не може займатися цивільним менеджментом. Натомість військові контролювали діяльність цивільної адміністрації на місцях, активно використовуючи іслам для зміцнення свого становища, будучи проти монополізації влади ісламістами. 1 березня 1962 р. була опублікована нова Конституція, яка перетворила Пакистан на президентську республіку. Влітку того ж року легалізувала свою діяльність партія «Мусульманська ліга». У 1967 р. Зульфікар Алі Бхутто створив «Партію пакистанського народу», яка опинилася в опозиції до Айюб-хана21. Після поразки у війні з Індією 1965 р. правлячий у Пакистані режим заглибився у кризу.

25 березня 1969 р. М. Айюб-хан передав владу генералу А.М.Яхья-хану (19171981). Однак лідер «Партії пакистанського народу» Зульфікар Алі Бхутто переміг на виборах 1970 р. з концепцією «ісламського соціалізму». Хоча реально програма його партії була досить секулярною і не зовсім соціалістичною. Внаслідок відділення Східної провінції у 1971 р. Пакистан втратив важливий ринок збуту своїх промислових виробів.

Після втрати Східного Пакистану 20 грудня 1971 р. А.М. Яхья-хан пішов у відставку та передав владу 3.А. Бхутто. Його уряд націоналізував частину пакистанської промисловості та провів аграрну реформу. У червні 1972 р. під час переговорів з Індірою Ганді у Сімлі 3.А. Бхутто показав себе вправним дипломатом. Беназір Бхутто згадувала, що «Індіра Ганді діяла з позиції сили, вимагаючи загальної угоди, яка мала врегулювати статус Кашміру. Пакистан пропонував рухатися крок за кроком»22.

У 1972 р. загострилися протиріччя між «Пакистанською народною партією» й ісламістами з партії «Джамаат ісламі» з приводу визнання незалежності Бангладеш. Вони звинуватили 3.А. Бхутто у відході від традиційних ісламських цінностей і способу життя. 14 березня 1973 р. набула чинності нова Конституція, яка повернула Пакистан до республіканського парламентського устрою та федералізму.

\footnotetext{
лам. Взгляд из Индии и России. Москва, 2010. С. 50.

19 Плешов О. Ислам и политическая культура общества... С. 29.

${ }^{20}$ Haqqani H. Op. cit. P. 45.

${ }^{21}$ Викрам Суд. Указ раб. С. 219.

22 Haqqani H. Op. cit. P. 81.
} 
Пакистанські військові опинилися у непростому становищі, позаяк конкуренцію їм почали складати радикальні ісламісти. Можна погодитися з думкою вітчизняного дослідника П.М. Ігнатьєва про те, що причинами ісламізації Пакистану є «відсутність легітимної центральної влади, яка здобувається шляхом переворотів військовим генералітетом, іï загравання 3 ісламсько-радикальними елементами, проблема об’єднання різних груп біженців у країні, тиск впливового ісламського лобі ззовні Пакистану на його політичні інститути, поширені бідність та безробіття» 23 . Однак і цивільна адміністрація 3.А. Бхутто у 1971-1977 pр. не змогла подолати глибоку внутрішньополітичну кризу в Пакистані. Утім, досі правові аспекти, інституційна й організаційна основа зовнішньополітичного курсу країни грунтується на положеннях Конституції Ісламської Республіки Пакистан, прийнятої у серпні 1973 р. Хоча, звичайно, впродовж декількох десятиріч неодноразово змінювалися зовнішньополітичні пріоритети Пакистану.

5 липня 1977 р. в Пакистані було встановлено третій за рахунком «військовобюрократичний режим» на чолі з генералом Мухаммадом Зія-уль-Хаком. Генерал вдало використав опозиційні настрої проти ЗА. Бхутто, які домінували у середовищі міського середнього класу, чимало членів якого були прихильниками радикальної партії «Джамаат ісламі». Зокрема, скасували запроваджений у січні 1977 р. сільськогосподарський податок на великих землевласників. Політика ісламізації у Пакистані, яку проводив «генерал-ісламіст», співпала з ісламською революцією в Ірані. Але створити цілком «ісламську державу» Зія-уль-Хак не хотів.

4 квітня 1979 р. колишнього прем'єр-міністра та лідера «Пакистанської народної партії» 3.А. Бхутто стратили, позаяк він залишався єдиним реальним конкурентом Зія-уль-Хака у боротьбі за владу. Беназір Бхутто не виключала того, що З.А. Бхутто Центральне розвідувальне управління США вирішило прибрати після його відмови анулювати розвиток пакистанської ядерної програми ${ }^{24} .16$ жовтня 1979 р. у Пакистані була заборонена легальна партійна діяльність. Родину Бхутто дозволяли згадувати у газетах лише у компрометуючих її новинах. Складними залишалися відносини між урядом з одного боку, армією та цивільною бюрократією - з іншого боку. Вони продовжували конкурувати за домінантне місце в ієрархії влади та за дефіцитні ресурси. Вперше в історії Пакистану в період правління генерала Зія-уль-Хака участь у владі брали фундаменталістські ісламські партії. Вони збиралися будувати «істинно ісламське суспільство загальної рівності та добробуту» 25.

Після ісламської революції 1979 р. в Ірані посилилося протистояння між пакистанськими шиїтами, підтриманими Іраном і сунітами, за якими стоїть Саудівська Аравія. Саудівські ваххабіти як мусульмани-суніти проводять політику посилення свого впливу серед переважної більшості пакистанських сунітів. Адже шиїти у Пакистані складають не більше 10 відсотків мусульман, тобто вони є конфесійною меншиною. 16 вересня 1979 р. Зія-уль-Хак виступив із пропозицію наведення «ісламського порядку», який мав забезпечити громадянам Пакистану можливість «вести ісламський образ життя» ${ }^{26}$. Цей крок можна розглядати як своєрідну сунітську реакцію на іранську шиїтську ісламську революцію. Пакистанська партія «Джамаат ісламі» стала найбільш активним прихильником розвитку пакистансько-саудівських

\footnotetext{
23 Ігнатьєв П.М. Вказ. пр. С. 271.

24 Haqqani H. Op. cit. P. 110.

25 Белокреницкий В.Я., Москаленко В.Н. Указ. раб. С. 314.

26 Тыссовский Ю.К. Указ. раб. С. 109.
} 
відносин.

Процес ісламізації посприяв глибокому розколу у пакистанському суспільстві. За даними перепису населення 1981 р. у Пакистані проживали 1 млн. 27 тис. індусів, 1 млн. 360 тис. християн, 104 тис. членів секти ахмадійців, 25 тис. сикхів, буддистів, парків, бахаїстів. Причому майже $20 \%$ населення країни на той час складали шиїти 27. 6 лютого 1981 р. «Партія пакистанського народу», «Мусульманська ліга» та низка ісламістських партій створили «Рух за підновлення демократії», який вимагав скасування військового стану та передачі влади цивільному уряду, скасування цензури та звільнення політичних в’язнів, проведення виборів відповідно до Конституції 1973 р., захист прав федеральних одиниць Пакистану.

19 грудня 1984 р. на референдумі було легалізовано урядовий курс ісламізації політики. Після цього було оголошено, що генерал Зія-уль-Хак став президентом на наступні п’ять років. Однак вибори до місцевих органів влади проводилися на непартійній основі. Тож з точки зору класичної демократії інтереси усіх груп пакистанського суспільства у формуванні політики національної безпеки представлені не були. Хоча, звичайно, пакистанська еліта стверджувала протилежне.

Також за правління Зія-уль-Хака в Пакистані були введені шаріатські суди. У науковій літературі цей крок пояснюється тим, що на відміну від Зульфікара Алі Бхутто, близького до синдхських суфійських шейхів, Зія походив із етнокастової групи арайн, яка найбільше постраждала від поділу Британської Індії. На думку Беназір Бхутто, «політика ісламізації поділила й деморалізувала країну. Більшість пакистанців ханафіти, прихильники поміркованого напрямку в ісламі, терпимі до релігійних меншин» 28.

Політика ісламізації допомагала залучати до Пакистану капітал із Саудівської Аравії. Іслам є у Пакистані державною ідеологією, яка інтегрує у пакистанську політичну націю різні племінні групи. Утім, значна частина пакистанських офіцерів вважала радикальну ісламізацію безперспективною. Однак пакистанські військові традиційно обгрунтовують свій прихід до влади політичною нестабільністю, загрозою безпеці країни, необхідністю захисту ісламу. Причому пакистанська армія, на відміну від турецької армії, за Зія-уль-Хака була одним із ініціаторів та інструментом ісламізації усіх сторін суспільного життя. За такого режиму мова не може йти навіть про обмежену демократію. Великі землевласники, буржуазія, середні прошарки, духовенство, вожді племен, цивільна бюрократія мають консолідовані зовнішньополітичні інтереси. Утім, радикальна частина опозиції режиму Зія-уль-Хака, об'єднана у «Рух за відновлення демократії», навіть закликала провінції Сінд, Белуджистан і Пуштуністан опонувати Пенджабу з приводу реалізації ідеї створення конфедерації як «порятунку пакистанської державності» 29.

У 1984 р. було створено «Національний фронт мухаджирів», який упродовж 19882002 рр. здобував прихильність мухаджирів у Карачі. Внаслідок цього Карачі стало місцем частих міжетнічних зіткнень. Окрім мухаджірів, на статус окремої нації претендують мешканці Пенджабу, які розмовляють мовою сірайкі, та белуджі, які активізувалися після 2003 р. Відтоді у провінції Белуджістан триває громадянська війна між місцевими повстанцями та пакистанською армією. Утім, більшість белуджів $є$

\footnotetext{
27 Воробьев В.В. Правление Мухаммада Зия-уль-Хака и его влияние на развитие Пакистана // Восток. 2011. № 1 . С. 85.

28 Тыссовский Ю.К. Указ. раб. С. 360.

${ }^{29}$ Ігнатьєв П.М. Вказ. пр. С. 179.
} 
сунітами, тому пріоритетним приводом до конфронтації є мовно-автономні права.

Скасування 30 грудня 1985 р. військового стану у Пакистані більше нагадувало рекламний трюк для Заходу. Передумовою цього було затвердження рішення про звільнення військового керівництва від відповідальності за дії, вчинені в умовах військового стану. Інтригу до внутрішньополітичного життя Пакистану у квітні 1986 р. внесло повернення до країни лідера опозиції Беназір Бхутто. Вже до 21 червня 1988 р. вона видала мемуарно-біографічну книгу «донька Сходу». Це засвідчило послідовність опозиції у підготовці до перехоплення влади у військових. Однак саме за правління Зія-уль-Хака військова влада сильно придушила й без того чахлі паростки демократичної політичної культури у Пакистані. Це обумовило складності з подоланням важкого політичного спадку правління Зія-уль-Хака30.

Після загибелі у авіаційній катастрофі 17 серпня 1988 г. президента Пакистану Зія-уль-Хака відбувалася суперечлива лібералізація політичного режиму. Позаяк Зіяуль-Хак у питанні ісламізації пакистанського суспільства готовий був йти до кінця, його смерть позбавила країну кровопролиття та відкрила шанс для повернення до демократії. Утім, під час чотирьох виборчих кампаній 1987-1997 рр. боротьба у Пакистані за владу відбувалася між представниками різних кланових інтересів. За цей час влада чотири рази переходила від «Пакистанської народної партії» до «Пакистанської мусульманської ліги» й у зворотному напрямку, але жоден уряд не був при владі увесь конституційний термін.

Головна боротьба на виборах до Національних зборів Пакистану, які проходили 16 листопада 1988 р., розгорнулася між «Партією пакистанського народу» на чолі 3 Беназір Бхутто й «Ісламським демократичним альянсом» (у складі Мусульманської ліги, «Джамаат ісламі» й інших мусульманських партій). Прем'єр-міністром стала Беназір Бхутто - донька страченого Зульфікара Алі Бхутто. Свій перший закордонних візит у січні 1989 р. вона зробила до Саудівської Аравії, де до 1988 р. був розквартирований пакистанський військовий контингент. Демонструючи пріоритет відносин із арабськими державами Перської затоки, Беназір Бхутто також відвідала Катар і Кувейт. У жовтні 1989 р. Пакистан відновив (вийшов 1971 р.) членство у Британській Співдружності націй.

У 1989 р. активізувалася громадянська війна в індійській частині штату Кашмір. П’ятнадцять радикальних ісламістських угруповань Кашміру створили «Об'єднану раду джихаду». Причому, за визнанням колишнього керівника Міжвідомчої розвідки Пакистану генерал-лейтенанта у відставці Хаміда Гула, «джихад у Кашмірі щорічно коштує Пакистану 100 млн. дол.» В свою чергу пакистанські спецслужби звинувачують Індію у фінансуванні терористичної діяльності руху мухаджирів (переселенців із Індію) у Сінді 31 .

Уряду Б. Бхутто довелося зіштовхнутися з радикалізацію моджахедів у Кашмірі, що негативно вплинуло на пакистансько-індійські відносини. Не менш складними були внутрішньополітичні проблеми, адже з травня 1990 р. у рідній провінції Бхутто - Сінд - тривали заворушення між корінними їі мешканцями та мухаджирами, тобто переселенцями з Індії. Але приймати рішення з цих проблем уряду Б. Бхутто не довелося. 6 серпня 1990 р. уряд Беназір Бхутто за звинуваченнями у корупції був відправлений у відставку. До того ж окупація 2 серпня 1990 р. іракськими військами

\footnotetext{
30 Воробьев В.В. Указ.раб. С. 85.

31 Ibid. C. 87.
} 
Кувейту нанесла збитки торговельно-економічним інтересам Пакистану. До цієї війни саме з Кувейту Пакистан отримував більшу частину нафти.

США, з метою звільнення Кувейту, пропонували Пакистану створити разом з Єгиптом і Туреччиною 100 тис. військовий контингент, але відповідно до пакистансько-саудівської угоди 1982 р. про співробітництво у сфері оборони Пакистан направив до Саудівської Аравії лише 10 тис. військовий контингент. Мотивом проти ширшої участі в операції у Перській затоці стали напружені відносини з Індією (Саудівська Аравія традиційно підтримує Пакистан у питанні «самовизначення на чесному i вільному плебісциті» населення Кашміру.). Рішення направити контингент до Саудівської Аравії було піддано критиці з боку пакистанських ісламістів, які вбачали в Іраку основного ворога Ізраїлю і не хотіли послаблення Багдаду. Позаяк, на думку Вашингтону, Пакистан у критичний момент проявив себе як ненадійний союзник, у жовтні 1990 р. конгрес США прийняв рішення про призупинення допомоги Ісламабаду. Не менш важливим фактором посилення ісламського радикалізму у Пакистані стали економічні негаразди. Це дало потужне ідеологічне обгрунтування поширенню політично мотивованого насилля.

24 жовтня 1990 р. на дострокових парламентських виборах перемогу святкував «ІІламський демократичний альянс», лідер якого Наваз Шариф став прем'єрміністром. Показово, що вже 18 квітня 1993 р. президент Гулам Ісхак-хан усунув від влади Н. Шарифа, але 26 травня 1993 р. суд визнав указ президента незаконним. Під тиском військових 18 липня 1993 р. президент і прем'єр-міністр одночасно пішли у відставку. На позачергових виборах 6 жовтня 1993 р. знову перемогла партія Беназір Бхутто. Її уряд продовжив політику економічної лібералізації. Однак у жовтні 1996 р., у найважчий для пакистанської економіки момент, Міжнародний валютний фонд відмовив у кредиті. Пакистан у цей час за міжнародними рейтингами вийшов на друге місце в світі по обсягам корупції, більше половини економіки країни перебували «у тіні».

В умовах системної кризи 5 листопада 1996 р. Президент Пакистану Ф. Легхарі розпустив парламент і відправив у відставку уряд Б. Бхутто. На чергових позачергових виборах 3 лютого 1997 р. перемогу святкувала «Пакистанська мусульманська ліга» на чолі з Наваз Шарифом. Зазначена партія опинилася при владі у всіх провінціях країни, за винятком Белуджистану. Уряд нарешті подолав опір великих землевласників і ввів податок на прибутки. В інтересах міжнародних економічних зв'язків Пакистану вихідний був перенесений з п'ятниці на неділю.У квітні 1997 р. були внесені зміни до Конституції, внаслідок яких президент втратив право розпускати парламент і відправляти у відставку уряд. За звинуваченнями у корупції були звільнені навіть військові. У серпні 1997 р. було прийнято антитерористичний закон. У жовтні 1997 р. королева Великої Британії Єлизавета II відвідала Пакистан. На той час при Президенті Пакистану було створено новий дорадчий орган - Раду оборони і національної безпеки. До їі складу увійшли керівники силових міністерств і збройних сил. Поява нової інституції мала закріпити роль президента та показати вирішальний вплив військових. Головним завданням цього органу стало вироблення рекомендацій голові держави щодо національної безпеки.

Визнавши поразку, 2 грудня 1997 р. пішов у відставку президент Ф. Легхарі. 31 грудня 1997 р. президентом став Мухаммад Рафік Тарар. Черговий період «парламентської демократії» у політичній історії Пакистану 1988-1999 рр. виявився суперечливим. Основна боротьба за владу точилася між «Пакистанською народною 
партією» Беназір Бхутто та «Мусульманською лігою» Н. Шарифа. Останній не підтримував антиамериканської політики. Утім, на період 1994-1999 рр. припадає активна «місіонерська» діяльність войовничих радикальних ісламських груп. У листопаді 1998 р. навіть Національна асамблея Пакистану прийняла шаріатське законодавство. За деякими даними, впродовж цього часу навикам ведення бойових дій у різних тренувальних «нелегальних таборах» навчилися близько 100 тис. пакистанців.

Висновки. Двічі пакистанський уряд у 1988-1990 рр. й у 1993-1996 рр. очолювала Беназір Бхутто. Її основний опонент від партії «Пакистанська мусульманська ліга» Наваз Шариф був прем'єр-міністром у 1990-1993 рр. й у 1997-1999 рр. Їхні зовнішньополітичні пріоритети стосувалися спроб залагодження протиріч із США. Вкрай негативне значення для стану економіки Пакистану мали запроваджені у відповідь на проведення ядерних випробувань 1998 р. санкції. Пакистан завершив XX ст. у стані політичної нестабільності та невизначеності. Перетворення країни на ядерну державу не змінило слабкої економіки, розмитості пакистанської ідентичності, не могло нейтралізувати міжконфесійні та міжетнічні протиріччя. Внаслідок цього у XXI ст. Пакистан увійшов як країна, що постійно продукує регіональну та глобальну нестабільність.

\section{REFERENCES}

Belokrenickii, V.Ya. (2008). Etnoregionnalnye i religiozno-sektanskie konflikty v Pakistane [Ethnoregional and religious-sectarian conflicts in Pakistan]. In Konflikty na Vostoke: etnicheskie i konfessionalnye (pp. 341-350). Moskva: Nauka [in Russian].

Belokrenickii, V.Ya. (2005). Personalistskiy avtoritarism v Pakistanie (k voprosu o politicheskoy culture i rezhyme vlasti v vostochom variante)[ Personalist authoritarianism in Pakistan (on the issue of political culture and regime of power in the eastern version)]. Vostok.6. 73-90. [in Russian].

Belokrenickii, V.Ya. \& Moskalenko, V.N. (2003). Istoriay Pakistana. XX vek. [The history of Pakistan. Twentieth century.]. Moskva: Institut vostokovedenia RAN. [in Rassian].

Benazir, Bhutto (1991). Doch vostoka [Daughter of the East]. Moskva: Politizdat [in Russian].

Bzhezinskii, Zb. (2012). Strategichne bachennia. Ameryka i kryza svitovoi vlady [Strategic Vision. America and the crisis of world power]. Lviv: Litopys [in Ukrainian].

Entsiklopediia Pakistana (1998). [Encyclopaedia of Pakistan]. Moskva: Vostochnaia literatura [in Russian].

Filimonova, A.L. (2010). Etnoregionalizm versus musulmanskaia obshnost v Britanskoi Indii [Ethnoregionalism versus Muslim community in British India]. Vostok, 5, 86-92 [in Russian].

Hafeez, M. (2001). Pakistan: Founders aspirations and today's realities. Oxford: Oxford University Press.

Haqqani, Hasan (2005). Pakistan: Between Mosque and Military. Washington: Cartoon Books.

Ignatev, P.M. (2006). Indiia na shliahu do liderstva v Pivdennii Azii [India on the Way to Leadership in South Asia]. Chernivci: Ruta [in Ukrainian].

Mathur, Alok (1994). "The 2-nation Theory». A Study in the Context of Crises in Pakistan. Jaipur: Publishing Books.

Pleshov, 0. (2003). Islam i politicheskaia kultura obshestva. Paradoksy konservativnoi tradicii [Islam and the political culture of society. Paradoxes of the conservative tradition]. Aziia i Afrika segodnia, 2, 20-32 [in Russian].

Pleshov, 0. (2003). Islam, islamizm i nominalnaia demokratiia v Pakistane [Islam, Islamism and Nominal Democracy in Pakistan]. Moskva: Vostochnaia literatura [in Russian].

Tyssovskii, Yu.K. (2011) «Krestonoscy» protiv islama [«Crusaders» against Islam]. T. 1. 
Moskva: Nauka [in Russian].

Vasilev, L.E. (2011). Osobennosti borby s terrorismom v stranakh Tsentralnoi Azii v sovremeenyh usloviiah [Features of the fight against terrorism in Central Asia in modern conditions]. In Mirovye derzhavy v Centralnoi Azii. Moskva: IDV RAN [in Russian].

Vikram, Sud (2010). Radikalnyi islam v regione i ego vliianie na Yuzhnuiu Aziiu [Radical Islam in the region and its influence on South Asia].In Radikalnyi islam. Vzgliad iz Indii $i$ Rossii (pp. 50-83). Moskva: MOF-ETC [in Russian].

Vilson, Dzhon (2010). Dolgaia voina radikalnogo islama v Pakistane [The long war of radical Islam in Pakistan]. In Radikalnyi islam. Vzgliad iz Indii i Rossii (pp. 401-403). Moskva: MOFETC [in Russian].

Vorobev, V.V. (2011). Pravlenie Muhammada Ziia-ul-Haka i ego vliianie na razvitie Pakistana [Reign of Muhammad Zia-ul-Haq and his influence on the development of Pakistan]. Vostok, 1, 85-97 [in Russian].

\section{Ihor Horobets}

(Sumy State Pedagogical University named after A.S. Makarenko, Sumy, Ukraine) ORCID: https://orcid.org/0000-0002-2416-7898

\section{Peculiar Features of the Historical Development of Pakistan Statehood}

The paper analyzes the main features of the historical development of Pakistan statehood. The idea of creating a «pure» Islamic state caused primarily the separation of Pakistan from British India in 1947. Since then, the Islamic factor has become crucial for the evolution of Pakistan statehood. Pakistan is a federation of tribes with weak central institutions, although the state has qualified post-colonial elite. Some Pakistani Muslims consider Islam to be a perfect religion that does not require a Western model of democracy. Others believe that Islam is democratic in its essence. In response, radical Islamists call Western forms of education incompatible with Islamic values. Pakistan political system is characterized by personalist authoritarianism as an authoritarian regime of power. Armed forces under the authoritarian regimes are not only the instrument of the power of ruling bureaucratic groups but also directly influence political processes, the transformation of social structures, development of the main trends of domestic and foreign policy. It is proved that the formation of the Pakistan political nation is complicated with interethnic, confessional, socio-economic and regional contradictions. Political elites in Pakistan had determined the confrontation with India as the strategic objective of the state. It is shown that the creation of atomic weapons only emphasized the asymmetry of the potential of India and Pakistan. The possession of atomic weapons could not solve the «tribal» problems of Pakistan statehood.

Keywords: statehood, Islam, Sunnis, Shiites, Pakistan, South Asia, atomic weapons 